\title{
Enhancement of Mercury Removal by Utilizing Catalytic Chelation Technique
}

\author{
Mubasher Furmuly 1,2, Faizuan Abdullah ${ }^{1, *}$, Ihsan Wan Azelee ${ }^{1}$, Razali Ismail ${ }^{1}$, Fuaad Omar ${ }^{1}$, Dedy Dwi \\ Prastyo ${ }^{3}$, Achmad Syafiuddin 4,* (D) \\ 1 Department of Chemistry, Faculty of Science, Universiti Teknologi Malaysia, 81310 UTM Johor Bahru, Johor, Malaysia \\ 2 Department of Analytical Chemistry, Faculty of Chemistry, Kabul University, Jamal Mina, Kabul, Afghanistan \\ 3 Department of Statistics, Faculty of Science and Data Analytics, Institut Teknologi Sepuluh Nopember, 60111 Surabaya, \\ East Java, Indonesia \\ 4 Department of Water and Environmental Engineering, Faculty of Engineering, Universiti Teknologi Malaysia, 81310 \\ UTM Johor Bahru, Johor, Malaysia \\ * Correspondence: faizuan@utm.my (F.A.); ac.syafi@gmail.com (A.S.);
}

Scopus Author ID 55053616200 (F.A.); 56682128000 (A.S.)

Received: 14.04.2020; Revised: 5.05.2020; Accepted: 6.05.2020; Published: 13.05.2020

\begin{abstract}
Discharge of heavy metals released from industries has adverse effects on the environment. The development of a method that can safely remove heavy metals is still challenging. Therefore, the aim of this study is to propose catalytic chelation technique for the removal of mercury $(\mathrm{Hg})$. Removal of $\mathrm{Hg}$ was carried out using the sodium acetate $\left(\mathrm{CH}_{3} \mathrm{COONa}\right)$ as the chelating agent and catalyzed by the heterogeneous alumina supported calcium oxide $\left(\mathrm{CaO} / \mathrm{Al}_{2} \mathrm{O}_{3}\right)$. The optimization was performed by applying the Response Surface Methodology (RSM) with the $\mathrm{pH}$ ranging from 7 to 10, a dosage of chelating agent from $400 \mathrm{ppm}$ to $600 \mathrm{ppm}$, temperature from 33.5 to $37.5^{\circ} \mathrm{C}$, and time of reaction from 1 to $5 \mathrm{~h}$. Hg content analysis was carried out using Flow Injection Mercury System based on cold vapor atomic absorption spectroscopy. X-ray diffraction (XRD) analysis revealed the presence of active sites on the catalyst. Field Emission Scanning Electron Microscopy (FESEM) analysis represented the formation of homogeneous particles on the catalyst surface. The Brunauer-Emmett-Teller (BET), Energy Dispersive X-Ray (EDX), and Fourier-transform Infrared Spectroscopy (FTIR) confirmed the surface area, the elemental composition, and functional groups of the catalyst, respectively. Moreover, the proposed method successfully achieved $\pm 99 \%$ of $\mathrm{Hg}$ removal.
\end{abstract}

Keywords: Mercury removal; chelation technique; catalyst; water pollution.

(C) 2020 by the authors. This article is an open access article distributed under the terms and conditions of the Creative Commons Attribution (CC BY) license (https://creativecommons.org/licenses/by/4.0/).

\section{Introduction}

Currently, the contaminated water becomes a major problem since Malaysia have concerned about industrial development [1-7]. A large amount of industrial pollutions containing poisonous chemicals especially heavy metals is released into water systems and are the main reason for seafood contamination by heavy metals [8-10]. The dosage of trace heavy metals in marine ecosystem is very low. However, some marine bivalves are capable of concentrating heavy metals in their tissues more than a million times compared to their concentration in the habitat [11]. Cockles are one of the marine mollusks which are widely consumed in Malaysia because it is easy to trap, a high biological value source of protein, vitamins, and minerals. They can be easily polluted by effluents coming from anthropogenic activities, sewage discharge, shipping activities, agricultural activities, and other contamination 
sources. It is a big concern for humans because the heavy metals coming from industrial effluents or by natural means are harmful and even can be carcinogenic to human.

The cockles are exposed to heavy metals such as cadmium, lead, arsenin, and mercury. The metals are toxic even in small amounts and can affect the immune system, nervous system, and reproductive system. There are three categories of heavy metals, namely, potentially toxic (arsenic, cadmium, lead, and mercury), probably essential (nickel, vanadium, and cobalt) and essential (copper, zinc, iron, and manganese). Since cockles are filter feeder organisms, so there is a high possibility of contamination by heavy metals, which are potentially poisonous, especially mercury which is one of the most toxic heavy metals and classified as potentially toxic heavy metals [12].

Furthermore, mercury is considered as a major environmental pollutant, since mercury mainly exists as $\mathrm{Hg}^{0}$ in the atmosphere which can stay there for a long period of time and can travel over a large geographical distance and can be absorbed by land or water [13]. As long as most of the accumulated mercury in trophic levels comes from dietary sources rather than from direct water intake, thus cockles as a filter feeder, consume phytoplankton at the bottom of the food chain which accumulates and transforms mercury from the environment [14]. Biotransformation of mercury species by marine phytoplankton is more important than the bioavailability of mercury in marine phytoplankton, in addition phytoplankton and other bacteria are able to reduce $\mathrm{Hg}(\mathrm{II})$ to volatile $\mathrm{Hg}^{0}$ which makes a global health concern $[15,16]$.

A number of methods and materials have been suggested for the removal of mercury from different environments [17-22]. For instance, high removal of mercury from chloralkali wastewater can be achieved by a biofilm of mercury-resistant bacteria [23]. Alternatively, the porous organic polymer-based mercury can effectively reduce the mercury (II) concentration from $10 \mathrm{ppm}$ to a fairly low concentration of $0.4 \mathrm{ppm}$ within a short period of time [24]. Of all the treatment techniques for the removal of heavy metals, the chelation technique is widely used as a treatment technique for the removal of heavy metals such as lead, mercury, and arsenic. Chelating agents such as ethylene diamine tetraacetic acid (EDTA), 2,3-dimercapto succinic acid (DMSA), and 2,3-dimercapto propansulfuric acid (DMPS) are used to bind heavy metals and excrete from the blood to urine. Moreover, chelation technique has been found to be a likely method for the removal of heavy metals to levels permissible by Malaysian food regulations.

In this work, we propose a catalytic chelation technique for the removal of mercury. This study provided an important opportunity to advance the understanding of the use of this technique for the removal of various heavy metals from the environment.

\section{Materials and Methods}

\subsection{Materials.}

Chemical and reagents of analytical grade have been used for this study and no purification has been done before using the chemicals. The chemicals were $65 \%$ Nitric acid, $\mathrm{HNO}_{3}\left(\mathrm{QRëC^{ \textrm {TM } }}\right)$ and 30\% Hydrogen peroxide, $\mathrm{H}_{2} \mathrm{O}_{2}$ (QRëC ${ }^{\mathrm{TM}}$ ) used for digestion, sodium acetate trihydrate, $\mathrm{CH}_{3} \mathrm{COONa} .3 \mathrm{H}_{2} \mathrm{O}$ (MERCK) as a chelating agent, calcium oxide on alumina support $\left(\mathrm{CaO} / \mathrm{Al}_{2} \mathrm{O}_{3}\right)$ as a catalyst, $0.05 \%$ Sodium hydroxide + Sodium borohydride as a reductant, $\mathrm{NaOH}+\mathrm{NaBH}_{4}\left(\mathrm{QRëC}{ }^{\mathrm{TM}}\right), 3 \% \mathrm{HCl}\left(\mathrm{QRëC}{ }^{\mathrm{TM}}\right)$ as a carrier, $5 \% \mathrm{KMnO}_{4}$, potassium permanganate for mercury samples, $10 \% \mathrm{HCl}$ for preparation of solutions, $1000 \mathrm{ppm}$ 
mercury $(\mathrm{Hg})$ stock solution (MERCK) for preparing mercury standard solutions. Ultra-pure water from a NANO pure water system has been used for all dilution purposes.

\subsection{Sample preparation.}

The Anadara granosa was purchased from a fisherman at Pontian, Johor Bahru, Malaysia and then transported to the analytical laboratory of Universiti Technologi Malaysia inside the ice boxes at a temperature of $4^{\circ} \mathrm{C}$ to avoid thermal degradation and microbial activity and acidified with concentrated nitric acid to $\mathrm{pH}<2$. Prior to removing the soft tissues of the cockles from its outer shell, the shell surface was washed with tap water to remove the specks of dirt and other contaminating organisms such as barnacles and bryzoa, then the samples were grounded and homogenized using a mixer and refrigerated at $-10^{\circ} \mathrm{C}$ for further treatment. Sample preparation was done according to the nitric acid digestion method adopted from Association of Official Agricultural Chemists (AOAC 999.10). In the preparation, a $0.5 \mathrm{~g}$ of the cockles was weighed into a digestion vessel and $5 \mathrm{~mL}$ of analytical grade $65 \% \mathrm{HNO}_{3}(\mathrm{w} / \mathrm{w})$ and $2 \mathrm{~mL}$ of $30 \% \mathrm{H}_{2} \mathrm{O}_{2}(\mathrm{w} / \mathrm{w})$ was added into the sample and then the digestion was conducted by the aid of a Microwave digester (Perkin Elmer Titan MPS ${ }^{\text {TM}}$ ) until a clear solution of the sample was produced. The sample was allowed to cool and then volumized with $25 \mathrm{~mL}$ of ultrapure water, 1-2 drops of $\mathrm{KMnO}_{4}$ was added to the samples in order to convert organically bound mercury to inorganic mercury ions at room temperature [25].

\subsection{Preparation of catalyst.}

Calcium nitrate tetrahydrate powder was prepared by mixing $5 \mathrm{~g}$ of it into the $5 \mathrm{~mL}$ of deionized water in a beaker $(250 \mathrm{~mL})$, then the mixture was heated and stirred until the complete dissolve of the powder and the mixture was allowed to cool to room temperature. The alumina pellets were immersed into the solution and left for an hour at room temperature before calcined in a muffle furnace at $900{ }^{\circ} \mathrm{C}, 1000{ }^{\circ} \mathrm{C}$, and $1100{ }^{\circ} \mathrm{C}$. Next, the pellets were aged at $80^{\circ} \mathrm{C}$ for 24 hours, and then calcined for 5 hours to prepare the proposed catalyst.

\subsection{Mercury removal.}

The flesh of the cockles was washed with deionized water after removing from its shell and then exposed to treatment with the chelating agent inside a $250 \mathrm{~mL}$ beaker, where the flesh was held inside the beaker with the aid of a string, and the solution was stirred using IKA HS7 magnetic stirrer during the treatment process. The treatment was done using different dosage of chelating agent $(200$ to $600 \mu \mathrm{L} / \mathrm{L})$, with the treatment temperature of $\left(32.50 \pm 0.50{ }^{\circ} \mathrm{C}\right.$ to $\left.37.50 \pm 0.50{ }^{\circ} \mathrm{C}\right)$, treatment time ranging from 1 hour to 5 hours and $\mathrm{pH}$ ranging from acidic $(\mathrm{pH}$ =4) to basic $(\mathrm{pH}=10)$ in order to obtain the optimized condition for the highest percentage removal of mercury from cockles. $\mathrm{CaO} / \mathrm{Al}_{2} \mathrm{O}_{3}$ was used as a catalyst during the treatment process and a $0.25 \mathrm{~g}$ of it was left in the beaker containing the chelating agent solution and was stirred throughout the treatment process. Each experiment was done with a replicate of three times in order to get the mean value and standard deviation concentration of the mercury inside the cockles.

\subsection{Fourier transforms infrared spectroscopy analysis.}

A Perkin Elmer flow-injection mercury system (FIMS-100) was used for the analysis of mercury content in the treated cockles, which is based on the cold vapor atomic absorption 
spectroscopy and contains a single peristaltic pump, elevated optics, low-pressure mercury lamp, and a solar-blind detector for high sensitivity. An auto-sampler injected the sample into the system and an acid carrier was used for transporting the sample to the mixing section. Next, the sample was mixed with the reductant and a vapor hydride of mercury was produced during the reaction which was purged by the aid of argon with a regulate pressure to the gas-liquid separator and was then carried to the FIMS cell for detection by the help of mercury lamp.

Sodium borohydride $\left(\mathrm{NaBH}_{4}\right)$ was used as a reductant which was prepared from a $0.05 \%$ solution of sodium hydroxide $(\mathrm{NaOH})$ and $0.2 \%$ sodium borohydride $\left(\mathrm{NaBH}_{4}\right)$. Hydrochloric acid, $(3 \% \mathrm{HCl})$ was used as the carrier and prepared by diluting the concentrated $\mathrm{HCl}$. A solution of $5 \% \mathrm{KMnO}_{4}$ was added to the digested samples. In order to prepare the standard solutions to plot the calibration curve, the $1000 \mathrm{ppm}$ mercury stock solution (MERCK) was used to make a $10 \mathrm{ppm}$ mercury as an intermediate stock solution then the standard series was made with the concentration of $1 \mathrm{ppb}, 2 \mathrm{ppb}, 5 \mathrm{ppb}$, and $10 \mathrm{ppb}$ with quality control of $6 \mathrm{ppb}$ into a $25 \mathrm{~mL}$ volumetric flask.

\subsection{Optimization of mercury removal.}

For the optimization purpose, the Box-Behnken design of Response Surface Methodology (RSM) was employed by multiple regression analysis [26-28]. The independent variables of this study were, the dosage of chelating agent (A), time of treatment (B), temperature (C), and $\mathrm{pH}$ of the solution (D). Table 1 shows the levels of each factor based on RSM approach. In the Design Expert, an equation is used in order to approximate the optimum value and determine the interaction between the variables, and a quadratic equation model was employed in this work.

Table 1. Experimental design for the mercury removal.

\begin{tabular}{l|c|c|c|c|c}
\multicolumn{1}{c}{ Factors } & Symbols & \multirow{2}{*}{ Units } & \multicolumn{3}{c}{ Range and levels } \\
\cline { 4 - 6 } & & & -1 & 0 & +1 \\
\hline Dosage & $\mathrm{A}$ & $\mathrm{mg} / \mathrm{L}$ & 400 & 500 & 600 \\
\hline Time & $\mathrm{B}$ & $\mathrm{h}$ & 1 & 3 & 5 \\
\hline Temperature & $\mathrm{C}$ & ${ }^{\circ} \mathrm{C}$ & 29.5 & 32.5 & 37.5 \\
\hline pH & $\mathrm{D}$ & & 4 & 7 & 10
\end{tabular}

\subsection{Characterization.}

In order to determine the active site of catalyst for enhancement of mercury depuration from cockles, the characterization was performed utilizing analytical techniques such as X-Ray Diffraction (XRD) using A Bru-ker AXS D8 automatic powder diffractometer, Field Emission Scanning Electron Microscopy (FESEM) using Zeiss Supra 35VP model, Energy Dispersion X-Ray (EDX), Nitrogen Absorption (BET surface area) using a Micromeritics 3flex instrument, and Fourier Transform Infrared Spectroscopy (FTIR) using a Thermo Nicolet-iS10 spectrometer. The characterizations were presented for the next section.

\section{Results and Discussion}

\subsection{Mercury removal.}

The regression model obtained from RSM study is graphically displayed by 3dimensional contour plots to illustrate the interactive effect of factors on the removal percentage of mercury from cockles. The 3-dimensional contour plots are displayed in Figure 1. The time of treatment combined with concentration has a significant interactive effect on 
percentage removal of mercury by a removal percentage of $( \pm 95 \%)$, at a concentration of 500 $\mathrm{mg} / \mathrm{L}$ and 1 hour of treatment. The increasing of time of treatment from 1 hour to 5 hours does not influence the removal of mercury as the increase of concentration.
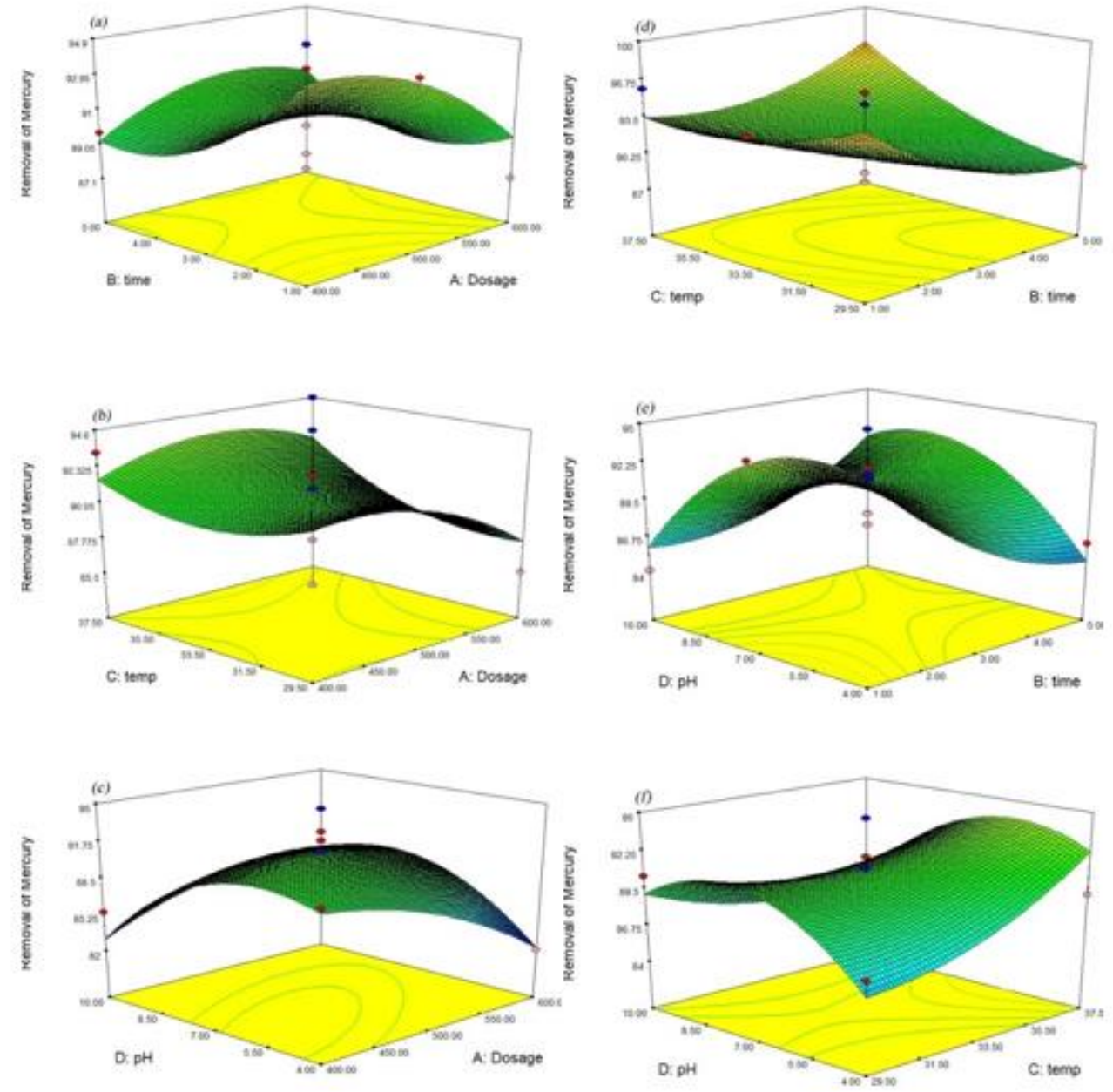

Figure 1. Three-dimensional contour plots for removal of mercury for (a) AB (b) AC (c) AD (d) BC (e) BD (f) CD. It is noted that $\mathrm{A}, \mathrm{B}, \mathrm{C}$, and $\mathrm{D}$ are dosage of chelating agent, time of treatment, temperature, and $\mathrm{pH}$ of the solution, respectively.

The time of treatment combined with the temperature is another significant interaction with a percentage removal of $( \pm 99 \%)$. The increase in both variables did not influence the removal percentage of mercury and was maximum at temperature $29.5{ }^{\circ} \mathrm{C}$ and treatment time of 1 hour. Furthermore, the combination of $\mathrm{pH}$ and time of treatment also has a remarkable role on the removal of mercury with a percentage of $( \pm 94 \%)$ at $\mathrm{pH}$ of 7 and 1 hours of treatment. The removal percentage increases with increment of $\mathrm{pH}$ of the solution from acidic $(\mathrm{pH} 4)$ to neutral media ( $\mathrm{pH} 7)$, meanwhile, the increasing time of treatment has not a significant role in percentage removal of mercury compared to the $\mathrm{pH}$ of the solution. The present study revealed an improved performance compared to previous studies in terms of percentage removal. For instance, the removal of mercury using activated carbons derived from organic sewage sludge can only be achieved by up to $83 \%$ [29]. Alternatively, the maximum mercury removal by nonviable biomass of an estuarine Bacillus sp. was by $92 \%$ [30].

\subsection{XRD analysis.}

In order to investigate the crystallinity of $\mathrm{CaO} / \mathrm{Al}_{2} \mathrm{O}_{3}, \mathrm{XRD}$ analysis was performed and the data obtained from the analysis is presented in Figure 2. It is noted from the figure that the 
catalyst calcined at $900{ }^{\circ} \mathrm{C}$ has a broad amorphous pattern which represents a low degree of crystallinity in the catalyst. According to the diffractogram, $\mathrm{Al}_{2.66} \mathrm{O}_{4}$ is the only alumina support species which is present in cubic phase at $2 \theta=67.181^{\circ}, 45.832^{\circ}$ and $37.435^{\circ}$, while none of the active metal species are present at this calcination temperature. The $\mathrm{CaO} / \mathrm{Al}_{2} \mathrm{O}_{3}$ calcined at $1000{ }^{\circ} \mathrm{C}$ represents a high degree of crystallinity based on the sharp peaks in diffractograms, furthermore, orthorhombic $\mathrm{Al}_{2} \mathrm{O}_{3}$, monoclinic $\mathrm{CaAl}_{4} \mathrm{O}_{7} / \mathrm{CaO} .2 \mathrm{Al}_{2} \mathrm{O}_{3}$, and cubic $\mathrm{Ca}_{12} \mathrm{Al}_{14} \mathrm{O}_{33}$ are three new species which were present at this calcination temperature which was revealed at $2 \theta=67.354^{\circ}, 66.767^{\circ}, 45.881^{\circ}, 45.407^{\circ}, 34.554^{\circ}$ and $36.568^{\circ}$ for orthorhombic $\mathrm{Al}_{2} \mathrm{O}_{3}$. However, due to the solid state reaction, there are another two phases which noticed at $2 \theta=$ $25.494^{\circ}, 34.554^{\circ}, 19.990^{\circ}, 28.989^{\circ}, 30.528^{\circ}$ and $33.032^{\circ}$ for monoclinic $\mathrm{CaAl}_{4} \mathrm{O}_{7} / \mathrm{CaO}_{2} 2 \mathrm{Al}_{2} \mathrm{O}_{3}$ while at $2 \theta=18.412^{\circ}, 33.427^{\circ}$ and $36.568^{\circ}$ for cubic $\mathrm{Ca}_{12} \mathrm{Al}_{14} \mathrm{O}_{33}$.

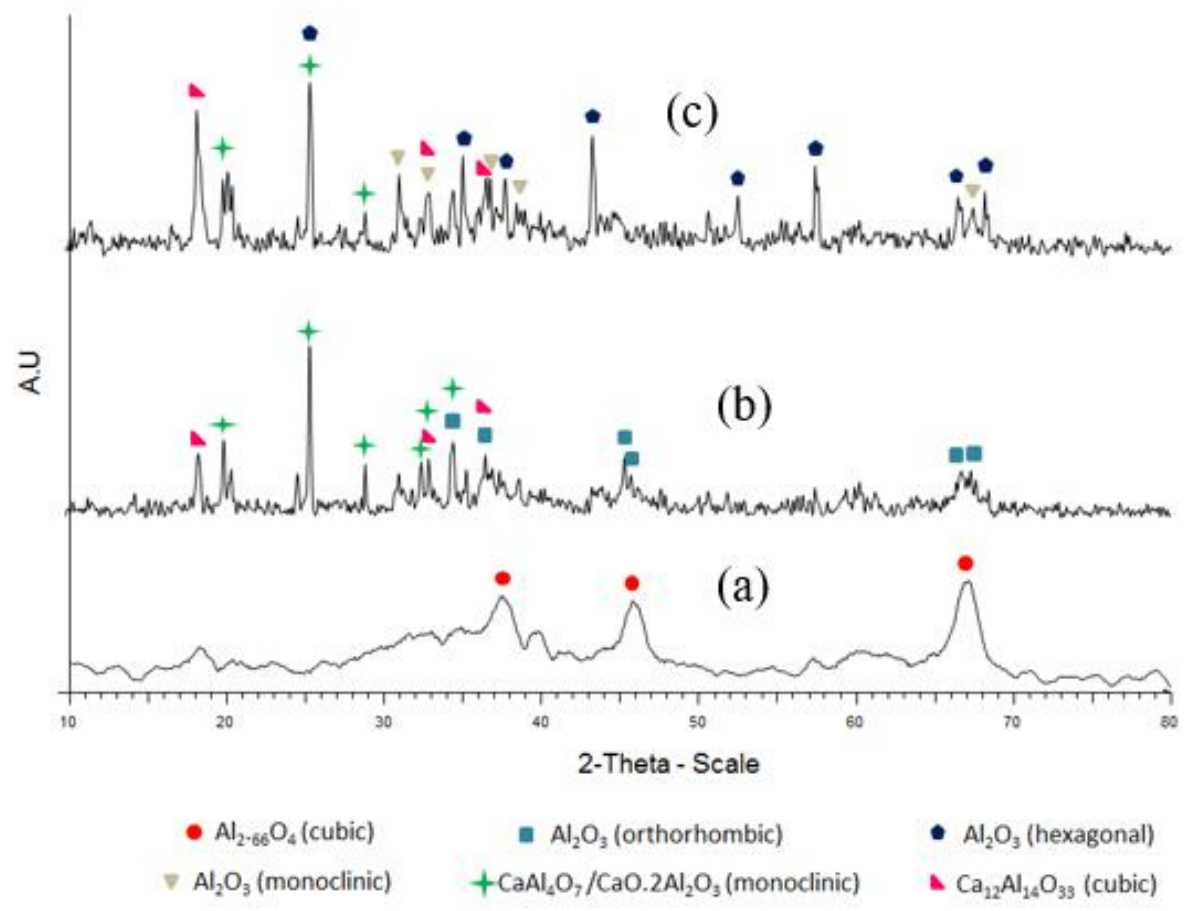

Figure 2. XRD Diffractograms of $\mathrm{CaO} / \mathrm{Al}_{2} \mathrm{O}_{3}$ at different temperatures at (a) $900^{\circ} \mathrm{C}$, (b) $1000^{\circ} \mathrm{C}$, and (c) 1100 ${ }^{\circ} \mathrm{C}$.

At the calcination temperature of $1100{ }^{\circ} \mathrm{C}$, the peaks were observed to be even more intense compared to the calcination temperature at $1000{ }^{\circ} \mathrm{C}$. The dominated phase by alumina support was increased into two phases which were different from those in $1000{ }^{\circ} \mathrm{C}$ calcination temperature and presented as monoclinic and hexagonal $\mathrm{Al}_{2} \mathrm{O}_{3}$ that happened at $2 \theta=67.411^{\circ}$, $31.119^{\circ}, 32.980^{\circ}, 36.841^{\circ}, 38.858^{\circ}$ and $2 \theta=35.134^{\circ}, 43.353^{\circ}, 57.583^{\circ}, 25.466^{\circ}, 37.837^{\circ}$, $52.577^{\circ}, 68.192^{\circ}$, and $66.480^{\circ}$, respectively, as listed in Table 2. Similarly, monoclinic $\mathrm{CaAl}_{4} \mathrm{O}_{7} / \mathrm{CaO}_{2} 2 \mathrm{Al}_{2} \mathrm{O}_{3}$ and cubic $\mathrm{Ca}_{12} \mathrm{Al}_{14} \mathrm{O}_{33}$ species also occurred at $2 \theta=18.316^{\circ}, 33.419^{\circ}$, $36.625^{\circ}$ and $2 \theta=18.316^{\circ}, 33.419^{\circ}$, and $36.625^{\circ}$, respectively.

The data obtained from the experiment involving $\mathrm{CaO} / \mathrm{Al}_{2} \mathrm{O}_{3}$ catalyst at different calcination temperatures are presented in Table 2 . It demonstrates that the higher catalytic activity occurred at $1000{ }^{\circ} \mathrm{C}$ calcination temperature. It could be determined from the orthorhombic $\mathrm{Al}_{2} \mathrm{O}_{3}$ support which has the best alumina phase for the active species and there are other active site species in monoclinic $\mathrm{CaAl}_{4} \mathrm{O}_{7} / \mathrm{CaO}_{2} \mathrm{Al}_{2} \mathrm{O}_{3}$ and cubic $\mathrm{Ca}_{12} \mathrm{Al}_{14} \mathrm{O}_{33}$ phases as well. Furthermore, when the calcination temperature increased from $900{ }^{\circ} \mathrm{C}$ to $1000{ }^{\circ} \mathrm{C}$, the 
presence of active species also increased which was proven by the high crystallinity of the catalyst.

Table 2. Peaks assignment in the $\mathrm{X}$-ray diffraction patterns of $\mathrm{CaO} / \mathrm{Al}_{2} \mathrm{O}_{3}$ calcined at different temperatures.

\begin{tabular}{|c|c|c|c|}
\hline Catalyst & $2 \theta$ & d $(\AA)$ & d $(\AA)_{\text {ref }}$ \\
\hline \multirow{2}{*}{ Calcined at $900^{\circ} \mathrm{C}$} & 67.181 & 1.392 & 1.400 \\
\hline & 45.832 & 1.978 & 1.980 \\
\hline $\mathrm{Al}_{2.66} \mathrm{O}_{4}(\mathrm{c})$ & 37.435 & 2.400 & 2.390 \\
\hline \multirow[t]{2}{*}{ Calcined at $1000^{\circ} \mathrm{C}$} & 67.354 & 1.389 & 1.391 \\
\hline & 66.767 & 1.400 & 1.405 \\
\hline \multirow[t]{4}{*}{$\mathrm{Al}_{2} \mathrm{O}_{3}$ (or) } & 45.407 & 1.996 & 1.990 \\
\hline & 45.881 & 1.976 & 1.983 \\
\hline & 34.554 & 2.594 & 2.596 \\
\hline & 36.568 & 2.455 & 2.457 \\
\hline \multirow[t]{6}{*}{$\mathrm{CaAl}_{4} \mathrm{O}_{7} / \mathrm{CaO} \mathrm{AAl}_{2} \mathrm{O}_{3}(\mathrm{~m})$} & 25.494 & 3.491 & 3.500 \\
\hline & 34.554 & 2.594 & 2.599 \\
\hline & 19.990 & 4.815 & 4.440 \\
\hline & 28.989 & 3.078 & 3.080 \\
\hline & 32.528 & 2.750 & 2.753 \\
\hline & 33.032 & 2.710 & 2.712 \\
\hline \multirow{3}{*}{$\mathrm{Ca}_{12} \mathrm{Al}_{14} \mathrm{O}_{33}(\mathrm{c})$} & 18.412 & 4.815 & 4.891 \\
\hline & 33.427 & 2.678 & 2.679 \\
\hline & 36.568 & 2.455 & 2.445 \\
\hline \multirow[t]{2}{*}{ Calcined at $1100^{\circ} \mathrm{C}$} & 25.466 & 3.495 & 3.500 \\
\hline & 34.536 & 2.595 & 2.599 \\
\hline \multirow[t]{2}{*}{$\mathrm{CaAl}_{4} \mathrm{O}_{7} / \mathrm{CaO}_{2} \mathrm{Al}_{2} \mathrm{O}_{3}(\mathrm{~m})$} & 19.990 & 4.438 & 4.440 \\
\hline & 18.316 & 4.840 & 4.891 \\
\hline \multirow[t]{2}{*}{$\mathrm{Ca}_{12} \mathrm{Al}_{14} \mathrm{O}_{33}(c)$} & 33.419 & 2.679 & 2.679 \\
\hline & 36.841 & 2.437 & 2.445 \\
\hline \multirow{5}{*}{$\mathrm{Al}_{2} \mathrm{O}_{3}(\mathrm{~m})$} & 67.411 & 1.388 & 1.380 \\
\hline & 31.119 & 2.872 & 2.801 \\
\hline & 32.980 & 2.714 & 2.713 \\
\hline & 36.841 & 2.438 & 2.441 \\
\hline & 38.858 & 2.316 & 2.310 \\
\hline \multirow{8}{*}{$\mathrm{Al}_{2} \mathrm{O}_{3}$ (h) } & 35.134 & 2.552 & 2.552 \\
\hline & 43.353 & 2.085 & 2.086 \\
\hline & 57.583 & 1.599 & 1.602 \\
\hline & 25.466 & 3.494 & 3.481 \\
\hline & 37.837 & 2.376 & 2.380 \\
\hline & 52.577 & 1.739 & 1.741 \\
\hline & 68.192 & 1.374 & 1.374 \\
\hline & 66.480 & 1.405 & 1.405 \\
\hline
\end{tabular}

\subsection{Surface morphology.}

The morphology of the catalyst $\left(\mathrm{CaO} / \mathrm{Al}_{2} \mathrm{O}_{3}\right)$ was observed by FESEM, where the active area of the catalyst was determined by the formation of morphology on the surface of the catalyst which is contributed to the enhancement of mercury depuration from cockles. The FESEM micrographs of $\mathrm{CaO} / \mathrm{Al}_{2} \mathrm{O}_{3}$ catalyst calcined at $900{ }^{\circ} \mathrm{C}, 1000^{\circ} \mathrm{C}, 1100^{\circ} \mathrm{C}$ were presented in Figure 3. It is demonstrated that the catalyst has aggregation and agglomeration on the surface. The particles are not dispersed on the catalyst surface and have unspecific shape. In addition, the formation of particles with undefined shape, aggregation and agglomeration on its surface can be observed for the catalyst calcined at $1000{ }^{\circ} \mathrm{C}$ calcination temperature. At $1100{ }^{\circ} \mathrm{C}$ calcination temperature, the particles have large aggregation and agglomeration but less dense and dispersed.

At $1000{ }^{\circ} \mathrm{C}$ calcination temperature, highly dispersed particles were formed on $\mathrm{CaO} / \mathrm{Al}_{2} \mathrm{O}_{3}$ catalyst. The catalyst surface was not homogenized at $900{ }^{\circ} \mathrm{C}$ due to a low degree of crystallinity according to the XRD results, meanwhile, the catalyst has a disordered structure at $1100{ }^{\circ} \mathrm{C}$ calcination temperature which is due to the presence of two alumina support species on the catalyst surface according to the XRD results. Thus, it can be observed from the FESEM 
results that the $\mathrm{CaO} / \mathrm{Al}_{2} \mathrm{O}_{3}$ catalyst calcined at $1000{ }^{\circ} \mathrm{C}$ has the characteristics which are the reason for the high catalytic activity of $\mathrm{CaO} / \mathrm{Al}_{2} \mathrm{O}_{3}$ catalyst.

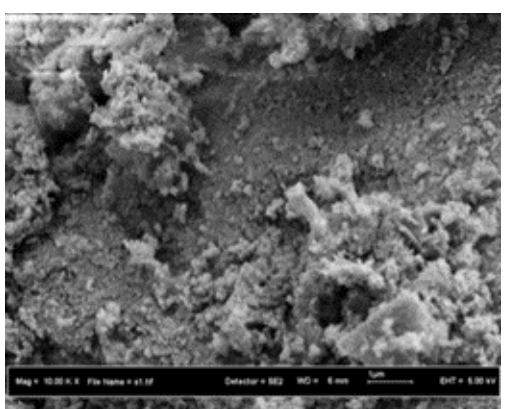

(a)

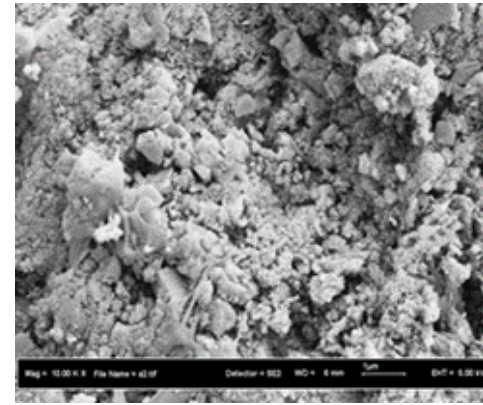

(b)

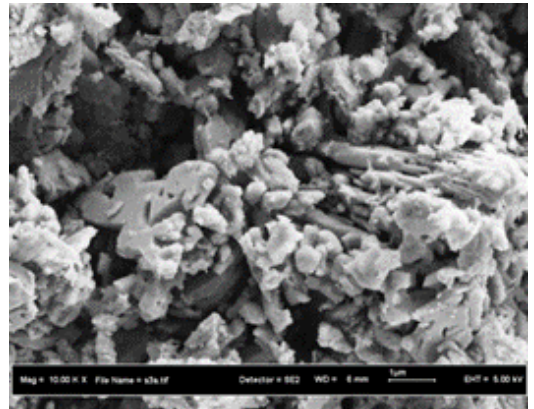

(c)

Figure 3. FESEM images of $\mathrm{CaO} / \mathrm{Al}_{2} \mathrm{O}_{3}$ catalyst calcined at (a) $900^{\circ} \mathrm{C}$, (b) $1000^{\circ} \mathrm{C}$, and (c) $1100^{\circ} \mathrm{C}$ with magnification of $10000 \mathrm{X}$.

\subsection{Nitrogen adsorption analysis.}

BET surface area analysis was performed to determine the surface area of the catalyst at different calcination temperatures as presented in Table 3 which demonstrates that the surface area of the catalyst is inversely proportional to the calcination temperature. It is in accordance with the XRD analysis representing an increase in the degree of crystallinity of catalyst decreased the surface area. The catalyst calcined at $1100{ }^{\circ} \mathrm{C}$ gave a low surface area $\left(11.54 \mathrm{~m}^{2} / \mathrm{g}\right)$ which is probably due to the large agglomeration and aggregation as described in FESEM analysis but regarding the catalytic activity results, catalyst calcined at $1000{ }^{\circ} \mathrm{C}$ showed the highest mercury removal which represents that the surface area parameter is not the only main factor for the mercury removal.

Table 3. BET surface area of $\mathrm{CaO} / \mathrm{Al}_{2} \mathrm{O}_{3}$ catalyst calcined at different temperatures

\begin{tabular}{l|c|c} 
Catalyst & Calcination temperature & \multicolumn{1}{c}{ Surface area $\left(\mathbf{m}^{2} / \mathbf{g}\right)$} \\
\hline \multirow{2}{*}{$\mathbf{C a O} / \mathrm{Al}_{2} \mathrm{O}_{3}$} & $900^{\circ} \mathrm{C}$ & 68.16 \\
\cline { 2 - 3 } & $1000^{\circ} \mathrm{C}$ & 33.22 \\
\cline { 2 - 3 } & $1100^{\circ} \mathrm{C}$ & 11.54
\end{tabular}

\subsection{EDX analysis.}

The composition of the element which has distributed and coated on the alumina support was analysed by EDX and the results are shown in Table 4. This study found that the presence of $\mathrm{O}, \mathrm{Al}$, and $\mathrm{Ca}$ was confirmed by the EDX analysis and the weight percentage of $\mathrm{Al}$ and $\mathrm{O}$ is higher than the $\mathrm{Ca}$ due to the presence of $\mathrm{Al}_{2} \mathrm{O}_{3}$ support for the catalyst.

Table 4. EDX Analysis of $\mathrm{CaO} / \mathrm{Al}_{2} \mathrm{O}_{3}$ catalyst calcined at different temperatures

\begin{tabular}{l|c|c|c}
\multirow{2}{*}{ Catalyst } & \multicolumn{3}{|c}{ Percentage (\%) } \\
\cline { 2 - 4 } & $\mathbf{O}$ & Al & Ca \\
\hline $\mathbf{9 0 0}{ }^{\circ} \mathbf{C}$ & 61.52 & 32.45 & 6.03 \\
\hline $\mathbf{1 0 0 0}^{\circ} \mathbf{C}$ & 57.43 & 35.93 & 6.64 \\
\hline $\mathbf{1 1 0 0}^{\circ} \mathbf{C}$ & 49.76 & 43.04 & 7.20
\end{tabular}

3.6. FTIR analysis.

The FTIR spectra of $\mathrm{CaO} / \mathrm{Al}_{2} \mathrm{O}_{3}$ catalyst calcined at different calcination temperatures are represented in Figure 4. The absorption bands between 579.02 to $811.18 \mathrm{~cm}^{-1}$ for $\mathrm{CaO} / \mathrm{Al}_{2} \mathrm{O}_{3}$ catalysts were due to the stretching mode of metal oxide $(\mathrm{M}=\mathrm{O})$ groups. Accordingly, the wavelength at $1420.97 \mathrm{~cm}^{-1}$ for the catalysts calcined at $1000^{\circ} \mathrm{C}$ and $1100^{\circ} \mathrm{C}$ 
indicates that the nitrate group in the catalyst had been completely removed, while the wavelength at $3436.38 \mathrm{~cm}^{-1}$ demonstrates the presence of $\mathrm{H}_{2} \mathrm{O}$ stretching group.

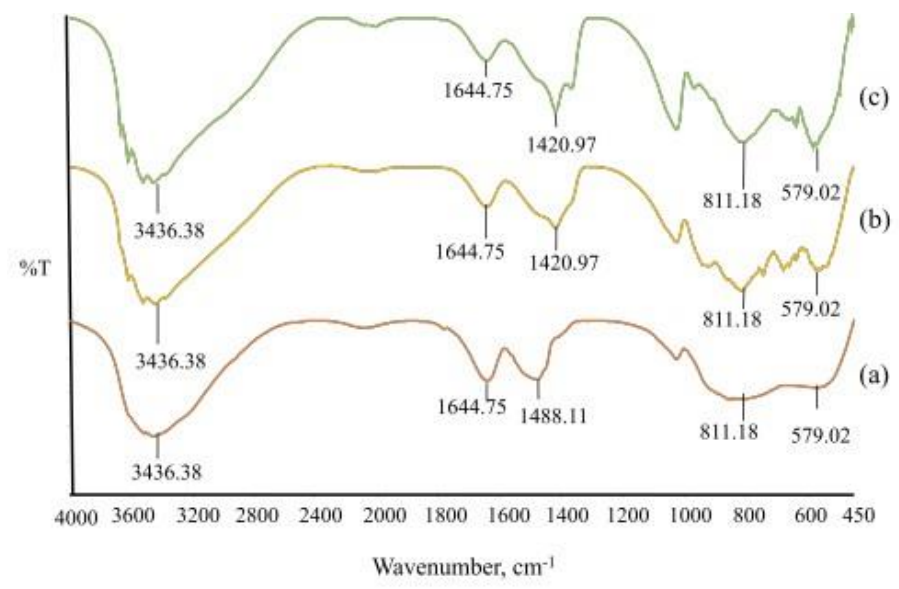

Figure 4. FTIR spectra of $\mathrm{CaO} / \mathrm{Al}_{2} \mathrm{O}_{3}$ catalyst calcined at (a) $900^{\circ} \mathrm{C}$, (b) $1000^{\circ} \mathrm{C}$ and (c) $1100^{\circ} \mathrm{C}$.

\section{Conclusions}

The present study aimed to propose a chelation technique for the removal of $\mathrm{Hg}$. RSM study revealed that the combined variables show a significant influence on percentage removal of mercury, which time of treatment and concentration had a significant interactive effect on percentage removal of mercury by a removal percentage of $( \pm 95 \%)$, at a concentration of 500 $\mathrm{mg} / \mathrm{L}$ and 1 hour of treatment. Time of treatment combined with the temperature was another significant interaction with a percentage removal of $( \pm 99 \%)$ and the combination of $\mathrm{pH}$ and time of treatment also had a remarkable role on the removal of mercury with a percentage of $( \pm 94 \%)$ at $\mathrm{pH}$ of 7 and 1 hour of treatment. $\mathrm{CaO} / \mathrm{Al}_{2} \mathrm{O}_{3}$ catalyst calcined at $1000{ }^{\circ} \mathrm{C}$ has remarkable performance because of its large surface area and presence of actives sites on catalyst confirmed by the XRD, FESEM, BET surface area, and EDX analyses.

\section{Funding}

This research was funded by the Universiti Teknologi Malaysia, grant number Q.J130000.2522.00H90.

\section{Acknowledgments}

The authors thank the Universiti Teknologi Malaysia for facilitating the research work.

\section{Conflicts of Interest}

The authors declare no conflict of interest.

\section{References}

1. Al Farraj, D.A.; Hadibarata, T.; Yuniarto, A.; Syafiuddin, A.; Surtikanti, H.K.; Elshikh, M.S.; Al Khulaifi, M.M.; Al-Kufaidy, R. Characterization of pyrene and chrysene degradation by halophilic Hortaea sp. B15. Bioprocess and Biosystems Engineering 2019, 42, 963-969, https://doi.org/10.1007/s00449-019-02096-8.

2. Hadibarata, T.; Syafiuddin, A.; Al-Dhabaan, F.A.; Elshikh, M.S.; Rubiyatno. Biodegradation of Mordant orange-1 using newly isolated strain Trichoderma harzianum RY44 and its metabolite appraisal. Bioprocess and Biosystems Engineering 2018, 41, 621-632, https://doi.org/10.1007/s00449-018-1897-0.

3. Syafiuddin, A.; Salmiati, S.; Jonbi, J.; Fulazzaky, M.A. Application of the kinetic and isotherm models for better understanding of the behaviors of silver nanoparticles adsorption onto different adsorbents. Journal of Environmental Management 2018, 218, 59-70, https://doi.org/10.1016/j.jenvman.2018.03.066. 
4. Syafiuddin, A.; Hadibarata, T.; Zon, N.F.; Salmiati. Characterization of titanium dioxide doped with nitrogen and sulfur and its photocatalytic appraisal for degradation of phenol and methylene blue. Journal of the Chinese Chemical Society 2017, 64, 1333-1339, https://doi.org/10.1002/jccs.201700136.

5. Hadibarata, T.; Syafiuddin, A.; Ghfar, A.A. Abundance and distribution of polycyclic aromatic hydrocarbons (PAHs) in sediments of the Mahakam River. Marine Pollution Bulletin 2019, 149, https://doi.org/10.1016/j.marpolbul.2019.110650.

6. Syafiuddin, A.; Fulazzaky, M.A.; Salmiati, S.; Kueh, A.B.H.; Fulazzaky, M.; Salim, M.R. Silver nanoparticles adsorption by the synthetic and natural adsorbent materials: an exclusive review. Nanotechnology for Environmental Engineering 2020, 5, 1-18, https://doi.org/10.1007/s41204-019-0065-3.

7. Syafiuddin, A.; Salmiati, S.; Hadibarata, T.; Salim, M.R.; Kueh, A.B.H.; Suhartono, S. Removal of silver nanoparticles from water environment: Experimental, mathematical formulation, and cost analysis. Water, Air, and Soil Pollution 2019, 230, 102-117, https://doi.org/10.1007/s11270-019-4143-8.

8. Alkarkhi, F.A.; Ismail, N.; Easa, A.M. Assessment of arsenic and heavy metal contents in cockles (Anadara granosa) using multivariate statistical techniques. Journal of Hazardous Materials 2008, 150, 783-789, https://doi.org/10.1016/j.jhazmat.2007.05.035.

9. Syafiuddin, A.; Salmiati, S.; Salim, M.R.; Kueh, A.B.H.; Hadibarata, T.; Nur, H. A review of silver nanoparticles: Research trends, global consumption, synthesis, properties, and future challenges. Journal of the Chinese Chemical Society 2017, 64, 732-756, https://doi.org/10.1002/jccs.201700067.

10. Syafiuddin, A. Toward a comprehensive understanding of textiles functionalized with silver nanoparticles. Journal of the Chinese Chemical Society 2019, 66, 793-814, https://doi.org/10.1002/jccs.201800474.

11. Kahle, J.; Zauke, G.P. Bioaccumulation of trace metals in the calanoid copepod Metridia gerlachei from the Weddell Sea (Antarctica). Science of the Total Environment 2002, 295, 1-16, https://doi.org/10.1016/S00489697(01)01147-0.

12. Pradit, S.; Shazili, N.A.M.; Towatana, P.; Saengmanee, W. Accumulation of trace metals in Anadara granosa and Anadara inaequivalvis from Pattani Bay and the Setiu Wetlands. Bulletin of Environmental Contamination and Toxicology 2016, 96, 472-477, https://doi.org/10.1007/s00128-015-1717-z.

13. Wu, Y.; Wang, W.X. Accumulation, subcellular distribution and toxicity of inorganic mercury and methylmercury in marine phytoplankton. Environmental Pollution 2011, 159, 3097-3105, https://doi.org/10.1016/j.envpol.2011.04.012.

14. Wang, W.X.; Wong, R.S. Bioaccumulation kinetics and exposure pathways of inorganic mercury and methylmercury in a marine fish, the sweetlips Plectorhinchus gibbosus. Marine Ecology Progress Series 2003, 261, 257-268, https://doi.org/10.3354/meps261257.

15. Fantozzi, L.; Ferrara, R.; Frontini, F.P.; Dini, F. Dissolved gaseous mercury production in the dark: evidence for the fundamental role of bacteria in different types of Mediterranean water bodies. Science of the Total Environment 2009, 407, 917-924, https://doi.org/10.1016/j.scitotenv.2008.09.014.

16. $\mathrm{Wu}, \mathrm{Y}$;; Wang, W.X. Intracellular speciation and transformation of inorganic mercury in marine phytoplankton. Aquatic Toxicology 2014, 148, 122-129, https://doi.org/10.1016/j.aquatox.2014.01.005.

17. Johs, A.; Eller, V.A.; Mehlhorn, T.L.; Brooks, S.C.; Harper, D.P.; Mayes, M.A.; Pierce, E.M.; Peterson, M.J. Dissolved organic matter reduces the effectiveness of sorbents for mercury removal. Science of the Total Environment 2019, 690, 410-416, https://doi.org/10.1016/j.scitotenv.2019.07.001.

18. Jampaiah, D.; Chalkidis, A.; Sabri, Y.M.; Mayes, E.L.H.; Reddy, B.M.; Bhargava, S.K. Low-temperature elemental mercury removal over TiO2 nanorods-supported MnOx-FeOx-CrOx. Catalysis Today 2019, 324, 174-182, https://doi.org/10.1016/j.cattod.2018.11.049.

19. Qin, H.; He, P.; Wu, J.; Chen, N. Theoretical study of hydrocarbon functional groups on elemental mercury adsorption on carbonaceous surface. Chemical Engineering Journal 2020, 380, https://doi.org/10.1016/j.cej.2019.122505.

20. Ahmad, M.; Wang, J.; Xu, J.; Yang, Z.; Zhang, Q.; Zhang, B. Novel synthetic method for magnetic sulphonated tubular trap for efficient mercury removal from wastewater. Journal of Colloid and Interface Science 2020, 565, 523-535, https://doi.org/10.1016/j.jcis.2020.01.024.

21. An, D.; Sun, X.; Cheng, X.; Cui, L.; Zhang, X.; Zhao, Y.; Dong, Y. Investigation on mercury removal and recovery based on enhanced adsorption by activated coke. Journal of Hazardous Materials 2020, 384, https://doi.org/10.1016/j.jhazmat.2019.121354.

22. Hao, R.; Wang, Z.; Mao, X.; Gong, Y.; Yuan, B.; Zhao, Y.; Tian, B.; Qi, M. Elemental mercury removal by a novel advanced oxidation process of ultraviolet/chlorite-ammonia: Mechanism and kinetics. Journal of Hazardous Materials 2019, 374, 120-128, https://doi.org/10.1016/j.jhazmat.2019.03.134.

23. Von Canstein, H.; Li, Y.; Timmis, K.; Deckwer, W.D.; Wagner-Döbler, I. Removal of mercury from chloralkali electrolysis wastewater by a mercury-resistant Pseudomonas putida strain. Applied and Environmental Microbiology 1999, 65, 5279-5284, https://doi.org/10.1128/AEM.65.12.5279-5284.1999.

24. Li, B.; Zhang, Y.; Ma, D.; Shi, Z.; Ma, S. Mercury nano-trap for effective and efficient removal of mercury (II) from aqueous solution. Nature Communications 2014. 5, 5537, https://doi.org/10.1038/ncomms6537.

25. Guo, T.z.; Baasner, J.; Gradl, M.; Kistner, A. Determination of mercury in saliva with a flow-injection system. Analytica Chimica Acta 1996, 320, 171-176, https://doi.org/10.1016/0003-2670(95)00459-9. 
26. Topal, M.; Arslan Topal, E.I. Optimization of tetracycline removal with chitosan obtained from mussel shells using RSM. Journal of Industrial and Engineering Chemistry 2020, 1, https://doi.org/10.1016/j.jiec.2020.01.013.

27. Gadekar, M.R.; Ahammed, M.M. Modelling dye removal by adsorption onto water treatment residuals using combined response surface methodology-artificial neural network approach. Journal of Environmental Management 2019, 231, 241-248, https://doi.org/10.1016/j.jenvman.2018.10.017.

28. Galedari, M.; Mehdipour Ghazi, M.; Rashid Mirmasoomi, S. Photocatalytic process for the tetracycline removal under visible light: Presenting a degradation model and optimization using response surface methodology (RSM). Chemical Engineering Research and Design 2019, 145, 323-333, https://doi.org/10.1016/j.cherd.2019.03.031.

29. Zhang, F.-S.; Nriagu, J.O.; Itoh, H. Mercury removal from water using activated carbons derived from organic sewage sludge. Water Research 2005, 39, 389-395, https://doi.org/10.1016/j.watres.2004.09.027.

30. Green-Ruiz, C. Mercury(II) removal from aqueous solutions by nonviable Bacillus sp. from a tropical estuary. Bioresource Technology 2006, 97, 1907-1911, https://doi.org/10.1016/j.biortech.2005.08.014. 